\title{
PENGGUNAAN TANAMAN HERBAL UNTUK KESEHATAN
}

\author{
Susilo Yulianto \\ Kementerian Kesehatan Politeknik Kesehatan Surakarta Jurusan Jamu
}

\begin{abstract}
The use of herbs, for health. Herbs are plants that can be used as drugs both leaves, stems, or roots. Herbs is partly used by the community for traditional or alternative medicine. Besides, the herb also has the advantage, that does not have side effects, treatment can be carried out by family members sendiri.Tanaman is an alternative herbal treatment that has been done by the people of Indonesia have traditionally. The successful use of herbal plants is strongly influenced by people's knowledge about the benefits of each type of medicinal plants, especially herbs that have been studied empirically. It is also influenced by how the use of each herb for a variety of different diseases. This study aims to determine the use of herbs for health. This research method is descriptive, with a sample of 53 respondents drawn by simple random sampling technique. The data collection conducted direct interviews with respondents and the open-air observation. Research instrument used was a questionnaire. The result showed that all respondents had been using herbs for health. The conclusion of this study was the use of herbs for health still needs to be improved further by providing the knowledge, awareness, willingness and ability of the community.
\end{abstract}

Keywords: The Use Of Plants Herbal, For Health

Abstrak: Penggunaan tanaman herbal, untuk kesehatan. Tanaman Herbal merupakan tanaman yang dapat dimanfaatkan sebagai upaya penyembuhan baik daun, batang, maupun akarnya.Tanaman Herbal ini sebagian digunakan masyarakat untuk pengobatan tradisional atau alternatif. Disamping itu tanaman herbal juga mempunyai kelebihan, yaitu tidak memiliki efek samping, pengobatan dapat dilakukan oleh anggota keluarga sendiri.Tanaman herbal merupakan salah satu alternatif pengobatanyang telah lama dilakukan oleh masyarakat Indonesia secara tradisional.Keberhasilan penggunaan tanaman herbal ini sangat dipengaruhi oleh pengetahuanmasyarakat mengenai manfaat dari setiap jenis tanaman yang berkhasiat obatterutama tanaman herbal yang telah diteliti secara empiris. Selain itu juga dipengaruhi oleh cara penggunaan masing-masing tanaman herbal untuk berbagaipenyakit yang berbeda. Penelitian ini bertujuan untuk mengetahui penggunaan tanaman herbal untuk kesehatan.Metode penelitian ini adalah deskriptif, dengan sampel sebanyak 53 responden yang diambil dengan teknik sampel acak sederhana. Pengumpulan data dilakukan secara wawancara langsung kepada responden dan observasi terbuka. Instrument penelitian yang digunakan ialah kuesioner. Dari hasil penelitian didapatkan bahwa seluruh responden pernah menggunakan tanaman herbal untuk kesehatan.Kesimpulan penelitian ini yaitu pemanfaatan tanaman herbal untuk kesehatan masih perlu ditingkatkan lagi dengan cara memberikan pengetahuan, kesadaran, kemauan dan kemampuan masyarakat.

Kata kunci: Penggunaan Tanaman Hebal, Untuk Kesehatan. 


\section{PENDAHULUAN}

Meningkatnya

kesadaran

masyarakatakan kesehatan, berpengaruh pula pada penggunaan obat herbal yang berasal dari tumbuhan dengan cara tradisional dan alami yang sudah dimanfaatkan oleh masyarakat Indonesia dari sejak nenek moyang kita. Hal ini banyak dilakukan masyarakat karena khasiatnya sudah terbukti dapat menyembuhkan penyakit, lebihmurah dan efek sampingnya lebih kecil dibandingkan dengan obat-obat konvensional. Tanaman obat berasal dari tumbuh-tumbuhan baik dari akarnya, daun, buah, bunga dan kulit kayunya.

Di Indonesia terdapat 20.000 jenis tumbuhan obat. Yang terdata sekitar 1.000 jenis, dan yang sudah dimanfaatkan untuk pengobatan tradisional baru sekitar 300 jenis.

Tanaman Herbal ialah Tanaman yang berkhasiat dalam penyembuahn atau pencegahan segala macam penyakit. Seiring dengan meningkatnya tingkat kesejahteraan, kesadaran dan kebutuhan akan perlunya hidup sehat, di antaranya perlunya makanan yang sehat yang diproduksi secara alami, tanpa penggunaan bahan-bahan kimia sintetis, meningkat pula. Produk pangan ini pada umumnya dihasilkan melalui budi daya organik atau kembali mengunakan yang alami. Gaya hidup sehat alami ini diikuti oleh penggunaan tanaman herbal yang alami, yaitu yang berasal dari tumbuhan yang di Indonesia diistilahkan dengan jamu. Tanaman herbal yang digunakan sebagai bahan obat ini mutlak harus terbebas dari bahan-bahan berbahaya dan harus diproduksi secara alami atau ramah lingkungan dan diistilahkan dengan budi daya organik tanaman obat, yang akhirakhir ini banyak digunakan masyarakat.
Penggunaan tanaman herbal untuk kesehatan keluarga dalam bentuk jamu dan bumbu dalam memasak.Penggunaan tanaman herbal juga dapat memberikan kepuasan, bahkan dapat membantu menopang perekonomian keluarga. Tanaman herbal juga dapat digunakan untuk meningkatkan kesehatan keluarga dan masyarakat.

Kesehatan keluarga dipengaruhi beberapa hal yaitu asupan gizi, pola makan, kurang olah raga dan gangguan kesehatan (Yusuf, 2002: 157). Gizi seimbang akan mempengaruhi kesehatan keluarga. Banyaknya makanan instan yang cepat saji yang banyak disukai, sangat berpengaruh terhadap kesehatan.

Bila anggota keluarga mengalami gangguan kesehatan, sesegera mungkin untuk mencari upaya penyembuhan yang dianggap dapat segera menyembuhkan penyakit tersebut, diantaranya ke rumah sakit, ke puskesmas, ke dokter, ke bidan atau menggunakan tanaman herbal.

Penelitian ini bertujuan untuk mengetahui penggunaan tanaman herbal untuk kesehatan.

\section{METODE PENELITIAN}

Jenis penelitian yang digunakan adalah penelitian deskriptif dengan pendekatan kuantitatiff. Rancangan penelitian Menggunakan cross sectional. Populasi dalam penelitian ini ialah para kepala keluarga.Pengambilan sampel dalam penelitian ini menggunakan purposive sampling, yaitu teknik penentuan sampel dengan pertimbangan tertentu (Soegiono, 2011). Sampel pada penelitian ini adalah 53 responden

\section{HASIL PENELITIAN}

Dari 53 responden yang diteliti, jumlah responden dengan umur $>40$ 
tahun merupakan kelompok umur yang terbanyak yaitu sebanyak 40 orang $(75,5$ $\%$ ), umur 30 - 40 tahun sebanyak 9 orang (17\%) dan yang terkecil adalah umur < 30 tahun sebanyak 4 orang $(7,5 \%)$.

\section{Tabel 1}

Distribusi Frekuensi Umur Kepala Keluarga

\begin{tabular}{llcc}
\hline No & $\begin{array}{l}\text { Tingkat } \\
\text { pendidikan }\end{array}$ & Jumlah & $\begin{array}{l}\text { Prosentase } \\
(\boldsymbol{\%})\end{array}$ \\
\hline 1. & SD & 37 & 69,8 \\
2. & SMP & 3 & 5,7 \\
3. & SMA & 11 & 20,7 \\
4. & PT & 2 & 3,8 \\
\hline & TOTAL & $\mathbf{5 3}$ & $\mathbf{1 0 0}$ \\
\hline & Mayoritas & responden & dengan
\end{tabular}
pendidikan SD sebanyak 37 orang $(69,8$ $\%$ ), sedangkan yang terkecil pada responden dengan tingkat pendidikan Perguruan Tinggi yaitu sebanyak 2 orang $(3,8 \%)$, SMP sebanyak 3 orang $(5,7 \%)$ dan SMA 11 orang $(20,7 \%)$.

\section{Tabel 2}

Distribusi Frekuensi Tingkat Pendidikan

\begin{tabular}{clcc}
\hline No & $\begin{array}{l}\text { Jenis } \\
\text { Kelamin }\end{array}$ & Jumlah & \multicolumn{2}{c}{$\begin{array}{l}\text { Prosentase } \\
(\boldsymbol{\%})\end{array}$} \\
\hline 1. & Laki-laki & 17 & 32,1 \\
2. & Perempuan & 36 & 67,9 \\
\hline & TOTAL & $\mathbf{5 3}$ & $\mathbf{1 0 0}$ \\
\hline & Responden & \multicolumn{2}{c}{ dengan jenis }
\end{tabular}

kelamin perempuan sebanyak 36 orang $(67,9 \%)$, sedangkan responden laki-laki sebanyak 17 orang $(32.1 \%)$.

Tabel 3

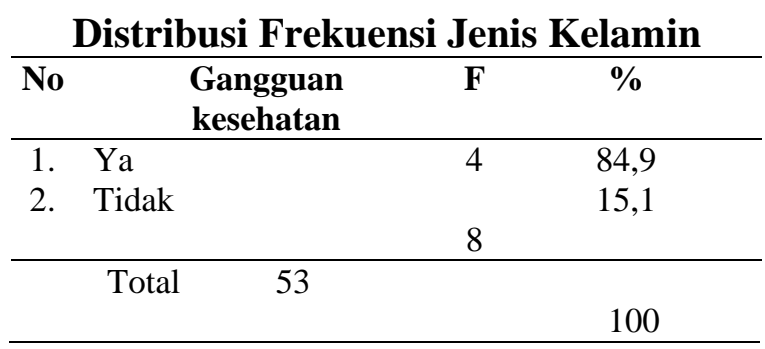

Anggota keluarga yang pernah mengalami ganggguan kesehatan sebanyak 45 (84,9\%), dan yang tidak pernah mengalami gangguan kesehatan sebanyak $8(15,1 \%)$.

Tabel 4

Distribusi Frekuensi Gangguan Kesehatan

\begin{tabular}{llll}
\hline No & $\begin{array}{l}\text { Umur } \\
\text { Responden }\end{array}$ & Jumlah & $\begin{array}{l}\text { Prosentase } \\
(\boldsymbol{\%})\end{array}$ \\
\hline 1. & $<30$ Tahun & 4 & 7,5 \\
2. & $30-40$ Tahun & 9 & 17 \\
3. & $>$ 40 Tahun & 40 & 75,5 \\
\hline & TOTAL & $\mathbf{5 3}$ & $\mathbf{1 0 0}$ \\
\hline & Anggota keluarga yang & pernah
\end{tabular}
mengalami penyakit parotitis sebanyak 38 anak $(71,7 \%)$ dan anak yang tidak pernah mengalami parotitis sebanyak 15 anak $(28,3 \%)$.

Tabel 5

Distribusi Frekuensi Penyakit Parotitis

\begin{tabular}{llll}
\hline No & $\begin{array}{c}\text { Penyakit parotitis } \\
\text { yang pernah } \\
\text { dialami anggota } \\
\text { keluarga }\end{array}$ & F & \% \\
\hline 1. & Ya & 38 & 71,7 \\
2. & Tidak & 15 & 28,3 \\
\hline & Total & 53 & 100 \\
\hline
\end{tabular}

Anggota keluarga yang diberikan bawang merah ketika panas sebanyak 42 $(79,2 \%)$ dan responden yang tidak memberikan bawang merah ketika panas sebanyak $11(20,8 \%)$.

Tabel 6

Distribusi Frekuensi pemberian bawang merah

\begin{tabular}{|c|c|c|c|}
\hline No & $\begin{array}{c}\text { Pemberian } \\
\text { Bawang Merah }\end{array}$ & $\mathbf{F}$ & $\%$ \\
\hline 1. & $\mathrm{Ya}$ & 42 & 79,2 \\
\hline 2. & Tidak & 11 & 20,8 \\
\hline
\end{tabular}


Kepala Keluarga yang memberikan jeruk nipis ketika anggota keluarga yang mengalami batuk sebanyak 42 responden $(79,2 \%)$ dan yang tidak memberikan jeruk nipis ketika anggota keluarga mengalami batuk sebanyak 11 responden $(20,8 \%)$.

\section{PEMBAHASAN}

Penelitian yang dilakukan, dengan 53 responden didapatkan karakteristik responden dan analisis penggunaan tanaman herbal untuk kesehatan keluarga. Responden paling banyak berumur lebih dari 40 tahun, dengan persentase $75,5 \%$ dan responden paling sedikit berumur kurang dari 30 tahun, dengan persentase $7,5 \%$.

Tingkat pendidikan SD sebanyak 37 responden, dengan persentase 69,8\% dan responden paling sedikit dengan tingkat pendidikan Perguruan Tinggi sebanyak 2 responden, dengan persentase $3,8 \%$.

$\begin{array}{llr}\text { Jenis } & \text { kelamin } & \text { perempuan } \\ \text { sebanyak } 36 \quad \text { responden, dengan }\end{array}$
persentase $67,9 \%$ dan responden paling sedikit dengan jenis kelamin laki-laki sebanyak 17 responden, dengan persentase $32,1 \%$.

Dari 53 responden, sebagian besar responden berjenis kelamin perempuan, yaitu 36 perempuan dan 17 laki-laki, karena pada umumnya ibu rumah tangga yang lebih rajin menjaga kesehatan anggota keluarganya.

Anggota keluarga yang pernah mengalami gangguan kesehatan sebanyak 45 orang dengan persentase $84,9 \%$ dan yang tidak pernah mengalami gangguan kesehatan 8 anak dengan persentase $15,1 \%$. Sebagian besar anggota keluarga pernah mengalami sakit, hal ini berpotensi menggunakan tanaman herbal.
Yang pernah mengalami sakit parotitis (gondongan) sebanyak 38 anggota keluarga dengan persentase $71,7 \%$ dan yang tidak pernah mengalami parotitis sebanyak 15 anggota keluarga dengan persentase $28,3 \%$.

Kepala keluarga yang memberikan bawang merah ketika anggota keluarga mengalami panas sebanyak 42 responden dengan persentase $79,2 \%$ dan kepala keluarga yang tidak memberikan bawang merah ketika anggota keluarga panas sebanyak 11 responden dengan persentase 20,8\%. Dari 53 responden sebagian besar pernah mengalami sakit yaitu parotitis dan panas.

Yang memberikan jeruk nipis ketika anggota keluarga mengalami batuk sebanyak 42 responden dengan persentase $79,2 \%$ dan kepala keluarga yang tidak memberikan jeruk nipis ketika anggota keluarga mengalami batuk sebanyak 11 responden dengan persentase $20,8 \%$.

Pemberian jahe ketika anggota keluarga mengalami pilek sebanyak 29 responden dengan persentase $54,7 \%$ dan yang tidak memberikan jahe ketika anggota keluarga mengalami pilek sebanyak 24 responden dengan persentase $45,3 \%$. Sebagian besar responden menggunakan tanaman herbal bila mengalami sakit seperti jeruk nipis dan jahe.

Pemberian kencur ketika anggota keluarga mengalami radang tenggorokkan sebanyak 39 responden dengan persentase $73,6 \%$ dan kepala keluarga yang tidak memberikan kencur ketika anggota keluarga mengalami radang tenggorokkan sebanyak 14 responden dengan persentase $26,4 \%$. Sebagian besar responden yaitu dari 53 responden menggunakana tanaman herbal kencur untuk menyembuhkan radang tenggorokan sebanyak 39 responden. 
Memberikan temu girirng ketika anggota keluarga mengalami cacingan sebanyak 14 responden dengan persentase $26,4 \%$ dan kepala keluarga yang tidak memberikan temu giring ketika anggota keluarga mengalami cacingan sebanyak 39 responden dengan persentase $73,6 \%$. Tanaman herbal temu giring belum banyak digunakan untuk cacingan karena banyak responden yang belum tahu.

Daun sirih ketika anggota keluarga mimisan sebanyak 50 responden dengan persentase $94,3 \%$ dan yang tidak memberikan daun sirih ketika anggota keluarga mengalami mimisan sebanyak 3 responden dengan persentase $5,7 \%$. Sebagian besar responden menggunakan daun sirih bila mimisan karena hal ini sudah sering digunakan di masyarakat.

Pemberian daun jambu biji ketika anggota keluarga mengalami diare sebanyak 43 responden dengan persentase $81,1 \%$ dan kepala keluarga yang tidak memberikan daun jambu biji ketika anggota keluarganya mengalami diare sebanyak 10 responden dengan persentase 18,9\%. Tanaman herbal daun jambu biji banyak digunakan ketika diare karena daun jambu biji efektif untuk menyembuhkan diare.

Memberikan pepaya ketika anggota keluarganya mengalami sembelit sebanyak 48 responden dengan persentase $90,6 \%$ dan yang tidak memberikan pepaya ketika anggota keluarganya mengalami sembelit sebanyak 5 responden dengan persentase 9,4\%. Sebagian besar responden menggunakan papaya ketika sembelit karena pepaya sudah banyak digunakan masyarakat untuk mengatasi sembelit.

Pemberian daun sirih ketika anggota keluarganya mengalami mata merah sebanyak 37 responden dengan persentase $69,8 \%$ dan kepala keluarga yang tidak memberikan daun sirih ketika anggota keluarganya mengalami mata merah sebanyak 16 responden dengan persentase $30,2 \%$. Responden belum banyak yang menggunakan daun sirih untuk mata merah, karena responden banyak yang belum tahu bila daun sirih juga dapat untuk mengatasi mata merah.

Memberikan lengkuas ketika anggota keluarganya mengalami gatalgatal sebanyak 21 responden dengan persentase $39,6 \%$ dan kepala keluarga yang tidak memberikan lengkuas ketika anggota keluarganya mengalami gatalgatal sebanyak 32 responden dengan persentase $60,4 \%$. Sebagian besar responden belum menggunakan tanaman herbal lengkuas karena keterbatasan pengetahuan responden, hal ini perlu ditingkatkan.

Beluntas ketika anggota keluarganya mengalami cacar sebanyak 13 responden dengan persentase 24,5\% dan kepala keluarga yang tidak memberikan beluntas ketika anggota keluarganya mengalami cacar sebanyak 40 responden dengan persentase $75,5 \%$. Beluntas juga dapat untuk mengatasi cacar (varisella),tetapi hal ini masih banyak responden yang belum menggunakan.

Pemberian daun pegagan ketika anggota keluarganya mengalami campak sebanyak 7 responden dengan persentase $13,2 \%$ dan kepala keluarga yang tidak memberikan daun pegagan ketika anggota keluarganya mengalami campak sebanyak 46 responden dengan persentase $86,8 \%$.

Kepala keluarga yang memberikan kunyit ketika anggota keluarganya mengalami amandel sebanyak 8 responden dengan persentase $15,1 \%$ dan kepala keluarga yang tidak memberikan kunyit ketika anggota keluarganya mengalami amandel 
sebanyak 45 responden dengan persentase $84,9 \%$. Sebagian besar responden belum menggunakan pegagan dan daun kunyit, karena responden banyak yang belum tahu.

Memberikan mengkudu ketika anggota keluarganya mengalami parotitis sebanyak 16 responden dengan persentase $30,2 \%$ dan kepala keluarga yang tidak memberikan mengkudu ketika anggota keluarganya mengalami parotitis sebanyak 37 responden dengan persentase $69,8 \%$.

Kepala keluarga yang mampu meracik ramuan herbal yang digunakan untuk mengatasi masalah kesehatan anggota kelurga sebanyak 11 responden dengan persentase 20,8\% dan kepala keluarga yang tidak mampu meracik ramuan herbal yang digunakan untuk mengatasi masalah kesehatan sebanyak 42 responden dengan persentase $79,2 \%$. Responden yang sudah mampu meracik ramuan herbal untuk kesehatan anggota keluarga masih sedikit, hal ini perlu ditingkatkan.

\section{KESIMPULAN DAN SARAN}

\section{A. Kesimpulan}

Tanaman herbal yang sering digunakanpara kepala keluarga untuk kesehatan yaitu bawang merah, jeruk nipis, jahe, kencur, temu giring, daun sirih, daun jambu biji, pepaya, lengkuas, beluntas, daun pegagan, kunyit dan mengkudu. Hal ini merupakan potensi yang sebaiknya masih perlu ditingkatkan, untuk membantu masyarakat dalam meningkatkan kesehatan dengan tanaman herbal.

Masalah kesehatan yang sering dialami anak yaitu parotitis (gondongan), panas, batuk, pilek, radang tenggorokan, cacingan, mimisan, diare, sembelit, belekan/mata merah, gatal-gatal, cacar, campak (gabagen) dan amandel. Sebagian besar responden pernah mengalami sakit dan sebagian besar sudah menggunakan tanaman herbal.

Penggunaan bawang merah untuk menurunkan panas, jeruk nipis untuk mengurangi batuk, Jahe untuk pilek, kencur untukradang tenggorokan, temu giring untuk cacingan, daun sirih untuk mimisan, daun jambu biji untuk diare, pepaya untuk sembelit, daun sirih juga dapat untuk mata merah, lengkuas untuk gatal-gatal, beluntas untuk cacar, daun pegagan untuk campak/gabagen, kunyit untuk amandel, mengkudu untuk parotitis. Kepala keluarga yang mampu meracik ramuan herbal untuk kesehatan keluarga hanya 20,8\% dan kepala keluarga yang tidak mampu meracik dengan benar ramuan herbal untuk mengatasi masalah kesehatan $79,2 \%$. Responden sudah mulai menggunakan tanaman herbal meskipun prosentasenya masih kecil, hal ini masih bisa ditingkatkan.

\section{B. Saran}

Berdasarkan hasil penelitian yang telah dilakukan, maka peneliti memberikan saran sebagai berikut:

1. Penggunaan tanaman herbal untuk kesehatan keluarga masih banyak digunakan. Oleh karena itu sebaiknya para kepala keluarga membudi dayakan dan mengembangkan tanaman herbal secara mandiri di halaman dan pekarangannya masing-masing, khususnya yang bermanfaat untuk kesehatan anggota keluarganya dan kesehatan masyarakat pada umumnya.

2. Bagi kepala keluarga sebaiknya meningkatkan kesadaran, kemauan dan kemampuan dalam menggunakan tanaman herbal untuk kesehatan keluarganya, dengan cara lebih banyak lagi menambah wawasan, ilmu 
pengetahuan, teknologi dan informasi tentang tanaman obat keluarga hingga meracik, mengkonsumsi dan khasiatnya.

3. Para kepala keluarga dalam menggunakan tanaman herbal untuk kesehatan masih sebatas untuk mengatasi bila mengalami masalah kesehatan, padahal yang paling baik yaitu memanfaatkan tanaman herbal sejak masih dalam kondisi sehat dengan memberikan tanaman-tanaman herbal yang berkhasiat untuk meningkatkan kesehatan (promotif) dan yang berkhasiat untuk mencegah terjadinya berbagai penyakit (preventif).

4. Para kepala keluarga sebaiknya meningkatkan penggunaan tanaman herbal karena relatif lebih aman, mudah, murah dan kecil efek sampingnya, selain itu merupakan salah satu upaya untuk menwujudkan derajat kesehatan masyarakat yang optimal secara mandiri.

5. Bagi peneliti, untuk menambah wawasan, pengetahuan dan ketrampilan dalam penelitian khususnya tentang penggunaan tanaman herbal untuk kesehatan keluarga. Bagi peneliti lain, dapat menjadi pertimbangan dan kajian dalam penelitian yang mendalam tentang penggunaan tanaman herbal untuk kesehatan keluarga.

\section{DAFTAR RUJUKAN}

Dalimartha, S,(1999), Atlas Tumbuhan Obat Indonesia Jilid I, Jakarta : Trubus Agriwidya

Hembing Wijayakusuma. (2000). Ensiklopedia milenium : Tumbuhan Berkhasiat Obat Indonesia, Jakarta : Gema Insani
Kartasapoetra, G. 1992. Budidaya Tanaman Berkhasit Obat. Jakarta : Rineka Cipta

Kementerian Kesehatan RI, (2011). Situasi Diare di Indonesia, Jakarta : Buletin Jendela Data dan Informasi Kesehatan Volume 2 Triwulan 2

Sulastomo, (2000).Manajemen kesehatan, Jakarta : Gramedia Pustaka Utama Supriyadi, (2001). Tumbuhan Obat Indonesia Penggunaan dan Khasiatnya, Jakarta : Pustaka. Populer

Wijayakusuma $\mathrm{HMH}$, Dalimartha $\mathrm{S}$ dan Wirian AS. (1993). Tanaman Berkhasiat Obat di. Indonesia. Jilid II, Jakarta : Pustaka Kartini

Wijayakusuma,HMH, (2007). Penyembuhan dengan Mengkudu. Jakarta : Penerbit Sarana Pustaka Afiat

Widyawati, (1999). Tanaman Obat Tradisional, Puslitbang Tanaman Pangan, Bogor. 